\title{
A Content Analysis of Bright 1: A 2013 Curriculum-Based Textbook for VII Grade Students
}

\author{
Ari Purwani ${ }^{1}$, Dewi Rochsantiningsih ${ }^{1}$, Diah Kristina ${ }^{1}$ \\ ${ }^{1}$ English Education Department, Graduate School, Faculty of Teacher Training and \\ Education, Universitas Sebelas Maret \\ E-mail: purwaniari24@gmail.com
}

\begin{abstract}
A content analysis of 'BRIGHT 1' English textbook is a research on the way a 2013 curriculum-based textbook is presented. This study reports on a content analysis investigating whether 'BRIGHT 1' for year VII students meets the characteristics of a good English textbook and reflects the 2013 curriculum. Data on content analysis were gathered from an English textbook entitled 'Bright 1'. Four evaluators and three classes of students were given questioners. They also were interviewed for verifying the data. A descriptive-evaluative content analysis was used in evaluating the textbook. The procedure of this research adopts the procedure suggested by Ur (2009: 185-187) that includes three steps as follows: deciding on criteria, applying criteria, and summary. This research applied two techniques of analysing the data that are manually counting the data from the questionnaire into percentages and adopting the procedure of data analysis by Miles and Huberman (1994) for the data from interview transcript. The procedure of data analysis included data reduction, data display, conclusion drawing and verification. Results showed that 'BRIGHT 1' English textbook has strengths and weaknesses. This textbook has reflected seven characteristics of a good English textbook and has implemented the scientific approach steps of 2013 curriculum. The other three aspects that are the Core Competences and the Basic Competences, the material, and the assessment standards are presented well in this textbook but some aspects are need to be improved.
\end{abstract}

\section{Keywords: a 2013 curriculum-based textbook; a descriptive-evaluative content analysis; a good English textbook.}

\section{INTRODUCTION}

In teaching and learning process of English language, numerous aspects could affect the outcomes of learning for students. These aspects could emerge from the pre-teaching preparations, while the teaching and learning are on progress, or after the teaching and learning take place. Teachers' roles are obviously important in teaching and learning process. They plan the syllabus, prepare the materials, and teach the classroom and so on. In addition, that is a whole lot of task to be done by a teacher. That is why media of a prepared teaching material is required. 
Textbook serves as a media that helps teachers in arranging a teaching and learning process. Therefore, preparing the teaching materials for each class will not consume lots of time. Besides, Cunningsworth (1995) mentions that the uses of textbook are considered helpful because most of the goals and aims have already been prepared in a set of practices based on what the students need to learn. Textbooks not only beneficial for teachers in terms of helping them to prepare the materials, and achieve the teaching aims and objectives but also helping students to achieve their learning needs. With well-prepared materials and test provided by the textbook, combined with teacher flexibility in teaching using the textbook in the class, a good compromise can be reached.

A textbook becomes an essential partner for teachers in teaching and learning process. A textbook usually overcomes the whole school curricula, the aims, goals, even the materials. That is why no one can guarantee the quality of a textbook used. The effectiveness of a textbook in arranging aims and goals, and preparing teaching materials becomes a good consideration before deciding to use the textbook in the classroom. An inappropriate textbook could possibly make the class dull with uninteresting exercise or too expensive for students or even does not match with the learner's rights in achieving their needs in learning. Those reasons make the selection of textbook used by teachers become relatively crucial.

The textbook has to fit with the current curriculum, school's syllabus along with student's needs and also the aims and goals of teaching. Therefore, teachers have to choose the appropriate and ideal textbook as beneficial for both students and teacher as possible.

Since 2014, a new curriculum, which is called the Kurikulum 2013 or curriculum 2013, is applied in all schools in Indonesia. The curriculum 2013 itself is different from the previous curriculum that is called KTSP. The implementation of this new curriculum requires adaptations in various aspects, including the textbooks supply.

Therefore, book publishers compete to offer various books based on curriculum 2013. Besides, the government provides student textbook and teacher guidebooks. One of the publishers is Erlangga that publishes a textbook named 'BRIGHT1'. The textbook is written by Nur Zaida.

It is important to know the quality of this textbook. BRIGHT 1 is used in MTsN Surakarta 1. To know whether the textbook fits the criteria and the characteristics of curriculum 2013, an evaluation must be done. Hence, BRIGHT 1 is evaluated. The proposed title is A Content Analysis of BRIGHT 1: A 2013 Curriculum-based Textbook for VII Grade Students

Two aspects could be considered in evaluating an English textbook. They are the implementation of the textbook in teaching and learning process and the content of the textbook. In evaluating the implementation of the textbook in the teaching and learning process, an empirical study can be done. In empirical study, the researcher could evaluate the book by gathering data from the teachers, students, and the teaching and learning process at school by doing interviews, distributing questionnaires, and conducting observations.

This study focuses on the content analysis of BRIGHT 1, the English textbook for year VII students. The content of textbook analysis is applied in analysing the book. A guide list of criteria must be prepared to determine the quality of a good textbook. The guide will be the parameter whether the textbook fulfils the criteria of 
a good textbook or not. The method which is chosen to evaluate BRIGHT 1 for year VII students is content analysis only.

The strengths of doing content analysis are it can allow for both quantitative and qualitative operations and allows closeness to text which can alternate between specific categories and relationship and also statistically analysis the coded form of the text. It also can be used to interpret text for purposes such as the development of expert systems (since knowledge and rules can be coded in terms of relationships among concepts). Despite of these strengths, content analysis has weaknesses such as it can be extremely time consuming, is inherently reductive (particularly when dealing with complex text), tends to simply, consists of word counts, and can be difficult to automate or computerize.

\section{RESEARCH METHOD}

The research was carried out at MTsN Surakarta 1, Surakarta, and Central Java. The object of this research was "BRIGHT 1" for year VII that was published by Erlangga Publisher. This textbook was chosen because it is used by teachers in MTsN Surakarta 1 as one of the teaching resources based on curriculum 2013. The subject of this research is four English teachers and three classes of students in MTsN Surakarta 1, in 2016/2017 academic year.

This research is designed as a descriptive-evaluative content analysis. Content analysis was used in evaluating the textbook. Berelson in Gall (2003: 278) states that content analysis is a research technique for the objective, systematic, and quantitative description of the manifest content of communication. Krippendorf (2004:18) defines content analysis as a research technique for making replicable and valid inferences from texts (or other meaningful matter) to the contexts of their use. Moreover, qualitative content analysis has been defined as a research method for the subjective interpretation of the content of text data through the systematic classification process of coding and identifying themes or patterns (Hsieh \& Shannon, 2005, p.1278). It is an approach of empirical, methodological, following content analytic rules and step by step models, without rush quantification (Mayring, 2000, p.2). It also can be defined as any qualitative data reduction and sense-making effort that takes a volume of qualitative material and attempts to identify core consistencies and meanings (Patton, 2002, p.453)

The goal of this research is only to analyse the content of BRIGHT1, in terms of whether the textbook meet the characteristics of a good textbook and reflect the 2013 curriculum for VII year English subject that includes the core competences and the and the basic competences, the steps of scientific approach, and the assessment standards.

Therefore, the procedure of this research adopts the procedure suggested by Ur (2009: 185-187). The procedure is presented as follows:

1. Deciding on Criteria

In this step, the criteria of good English textbooks were determined by taking into account English curriculum 2013, the criteria of good textbooks, and the checklist proposed by experts who discussed in the theoretical review. 
2. Applying Criteria

In this step, the criteria which had been determined were applied. The textbook was rated based on the criteria. After that, a description of BRIGHT 1 for year VII students was made based on the criteria.

3. Summary

In this step, conclusions were drawn based on the rating and descriptions. Then, an overall evaluation of BRIGHT 1 for year VII was made. The summary about the general statement of the quality of BRIGHT 1 for year VII was produced.

The data collecting techniques that are used in this research are the checklist of criteria of good English textbook based on curriculum 2013 and the interview. The data collecting instruments are a set of checklist for textbook evaluation which is in the form of questionnaire. This research uses two kinds of data collecting that are quantitative and qualitative checklist. Munkundan (2011:21) said that a checklist is an instrument that can help practitioners in ELT to evaluate teaching materials (textbook) and the checklist maybe quantitative or qualitative. In relation to the checklist development, the standards of curriculum 2013 in English subject and the textbook evaluation checklists by some experts were considered. For obtaining the data, the researcher analysed the textbook by herself and the four teacher and three classes of students are asked to fill out the questioners. For verifying the data, the four teachers are interviewed and the students are interviewed for their general opinion.

\section{RESULT AND DISCUSSION}

This study aims to discover whether 'BRIGHT 1' meets the characteristics of a good English textbook and to discover whether 'BRIGHT 1' meets the characteristic of 2013 curriculum based English textbook for VII year students.

\section{The Appropriateness to the Characteristics of a good English textbook}

For the characteristic of a good English textbook, the analyses are based on the book structure aspect and the content coverage aspect. These aspects are analysed by the researcher, the four evaluators, and the students. The summary of a good textbook analysis can be seen in the table 3.1. The results show that both of the two aspects contain strengths and weaknesses. The strengths are found on the following aspects: (1) the front pages that are cover page, copyright page, preface, and table of contents (2) the font is clear, not too small or too big (3) the chapter components that are objectives, explanations, activities, and evaluations (4) the grading tasks (5) the vocabulary explanation and tasks (6) the grammar explanation and the tasks (7) the listening skill. On the other hand, the weaknesses are found on the following aspects: (1) the back pages that are only the bibliography and the back cover (2) the pictures (3)the balance of chapter (4) the authenticity (5) the topics (6) the speaking skill (7) the writing skill (8) the reading skill (9) the pronunciation skill. 
TABLE I. THE SUMMARY OF ANALYSIS OF A GOOD ENGLISH TEXTBOOK CHARACTERISTICS BY THE RESEARCHER, THE EVALUATORS, AND THE STUDENTS

\begin{tabular}{|c|c|c|c|c|c|}
\hline \multirow[t]{3}{*}{ NO } & \multirow{2}{*}{\multicolumn{2}{|c|}{ Aspects }} & \multirow{2}{*}{\multicolumn{2}{|c|}{$\begin{array}{l}\text { Mean } \\
\text { Score/Percentage }\end{array}$}} & \multirow[t]{3}{*}{ Explanations } \\
\hline & & & & & \\
\hline & & & \multirow{2}{*}{$\begin{array}{l}\mathbf{R} \\
\mathbf{E}\end{array}$} & \multirow{2}{*}{ Students } & \\
\hline $\mathrm{a}$ & & $\begin{array}{l}\text { Book } \\
\text { Presentation }\end{array}$ & & & \\
\hline \multirow[t]{12}{*}{ 1) } & \multirow[t]{12}{*}{ a) } & $\begin{array}{l}\text { Book } \\
\text { Organization }\end{array}$ & & & \\
\hline & & Front Pages & 4 & & very good front pages \\
\hline & & $\begin{array}{l}\text { Chapters of } \\
\text { BRIGHT }\end{array}$ & & & \\
\hline & & Back Pages & $\begin{array}{l}2 . \\
8\end{array}$ & & almost good \\
\hline & & \multirow[t]{4}{*}{ Pictures } & \multirow[t]{4}{*}{3} & $\begin{array}{l}14 \% \text { strongly } \\
\text { agreed }\end{array}$ & $85-95 \%$ are interesting \\
\hline & & & & $63 \%$ agreed & many of the pictures are interesting \\
\hline & & & & $19 \%$ disagreed & various kinds but only white, blue, and black \\
\hline & & & & $\begin{array}{l}0 \% \text { strongly } \\
\text { disagreed }\end{array}$ & \\
\hline & & \multirow[t]{4}{*}{ Font } & \multirow[t]{4}{*}{4} & $\begin{array}{l}22 \% \text { strongly } \\
\text { agreed }\end{array}$ & always clear, not too small or too big \\
\hline & & & & $71 \%$ agreed & \\
\hline & & & & $7 \%$ disagreed & \\
\hline & & & & $\begin{array}{l}0 \% \text { strongly } \\
\text { disagreed }\end{array}$ & \\
\hline \multirow[t]{3}{*}{ 2) } & & $\begin{array}{l}\text { Chapter } \\
\text { Organization }\end{array}$ & & & \\
\hline & a) & $\begin{array}{l}\text { Balance of } \\
\text { Unit }\end{array}$ & 2 & & almost good, in range between $16-25$ pages \\
\hline & b) & $\begin{array}{l}\text { Chapter } \\
\text { Component }\end{array}$ & 4 & & very good, provided the four components \\
\hline \multirow[t]{17}{*}{$\mathrm{b}$} & & $\begin{array}{l}\text { Content } \\
\text { Coverage }\end{array}$ & & & \\
\hline & 1) & Authenticity & 3 & & $80-90 \%$ authentic materials, good. \\
\hline & \multirow[t]{4}{*}{ 2) } & \multirow[t]{4}{*}{ Topics } & \multirow[t]{4}{*}{3} & $\begin{array}{l}5 \% \text { strongly } \\
\text { agreed }\end{array}$ & $80-90 \%$ (many) interesting, uncovered some of the topics \\
\hline & & & & $88 \%$ agreed & $\begin{array}{l}\text { in reach to the students' knowledge and social life and able } \\
\text { to be practiced }\end{array}$ \\
\hline & & & & $7 \%$ disagreed & \\
\hline & & & & $\begin{array}{l}0 \% \text { strongly } \\
\text { disagreed }\end{array}$ & \\
\hline & \multirow[t]{11}{*}{ 3) } & Tasks & & & \\
\hline & & Grading Tasks & 4 & & $90 \%$ grading tasks, very good \\
\hline & & Micro Skills & & & \\
\hline & & \multirow[t]{4}{*}{ Pronunciation } & \multirow[t]{4}{*}{3} & $\begin{array}{l}30 \% \text { strongly } \\
\text { agreed }\end{array}$ & lack of phonetic transcription, accompanied by recordings \\
\hline & & & & $56 \%$ agreed & $\begin{array}{l}\text { many of the students believed this textbook can help them } \\
\text { study pronunciation easily }\end{array}$ \\
\hline & & & & $11 \%$ disagreed & good \\
\hline & & & & $\begin{array}{l}0 \% \text { strongly } \\
\text { disagreed }\end{array}$ & \\
\hline & & \multirow[t]{4}{*}{ Vocabulary } & \multirow[t]{4}{*}{4} & $\begin{array}{l}23 \% \text { strongly } \\
\text { agreed }\end{array}$ & very good \\
\hline & & & & $76 \%$ agreed & $\begin{array}{l}\text { most of the students believed that this textbook can help } \\
\text { them study vocabulary easily }\end{array}$ \\
\hline & & & & $0 \%$ disagreed & $\begin{array}{l}\text { from simple to complex, not too easy and not too difficult, } \\
\text { reviewed in the next chapter }\end{array}$ \\
\hline & & & & $\begin{array}{l}2 \% \text { strongly } \\
\text { disagreed }\end{array}$ & \\
\hline
\end{tabular}


TABLE I, cont.

\begin{tabular}{|c|c|c|c|}
\hline \multirow[t]{4}{*}{ Grammar } & \multirow[t]{4}{*}{4} & $\begin{array}{l}21 \% \text { strongly } \\
\text { agreed }\end{array}$ & more than $95 \%$ accurate \\
\hline & & $71 \%$ agreed & very good \\
\hline & & $8 \%$ disagreed & $\begin{array}{l}\text { most of the students believed that this textbook can help } \\
\text { them study grammar easily }\end{array}$ \\
\hline & & $\begin{array}{l}0 \% \text { strongly } \\
\text { disagreed }\end{array}$ & \\
\hline Macro skills & 4 & & very good \\
\hline \multirow[t]{4}{*}{ Listening } & & $\begin{array}{l}27 \% \text { strongly } \\
\text { agreed }\end{array}$ & provided completely, can be applied directly \\
\hline & & $65 \%$ Agreed & $\begin{array}{l}\text { most of the students believed that this textbook can help } \\
\text { them study listening easily }\end{array}$ \\
\hline & & $8 \%$ disagreed & \\
\hline & & $\begin{array}{l}0 \% \text { Strongly } \\
\text { disagreed }\end{array}$ & \\
\hline \multirow[t]{4}{*}{ Speaking } & & $\begin{array}{l}30 \% \text { strongly } \\
\text { agreed }\end{array}$ & $\begin{array}{l}\text { a lot of students believed that this textbook can help them } \\
\text { study speaking easily }\end{array}$ \\
\hline & & $54 \%$ agreed & \\
\hline & & $17 \%$ disagreed & \\
\hline & & $\begin{array}{l}0 \% \text { strongly } \\
\text { disagreed }\end{array}$ & \\
\hline \multirow[t]{4}{*}{ Reading } & & $\begin{array}{l}24 \% \text { Strongly } \\
\text { agreed }\end{array}$ & $\begin{array}{l}\text { many of the students believed this textbook can help them } \\
\text { study reading easily }\end{array}$ \\
\hline & & $63 \%$ agreed & \\
\hline & & $8 \%$ Disagreed & \\
\hline & & $\begin{array}{l}5 \% \text { strongly } \\
\text { disagreed }\end{array}$ & \\
\hline \multirow[t]{4}{*}{ Writing } & & $\begin{array}{l}16 \% \text { strongly } \\
\text { agreed }\end{array}$ & $\begin{array}{l}\text { Most of the students believed that this textbook can help } \\
\text { them study writing easily }\end{array}$ \\
\hline & & $66 \%$ agreed & \\
\hline & & $13 \%$ disagreed & \\
\hline & & $\begin{array}{l}5 \% \text { strongly } \\
\text { disagreed }\end{array}$ & \\
\hline
\end{tabular}

Note: R (Researcher), E (Evaluator)

\section{The Appropriateness to The Characteristic of 2013 Curriculum Based English Textbook for VII Year Students.}

For the characteristics of 2013 curriculum based textbook, this aspect is analysed by the researcher and the four evaluators. The summary of analysis of the characteristics of 2013 curriculum based English textbook for VII year students is presented in the table 3.2. The results show that the most prominent aspect that fulfils the appropriateness to the 2013 curriculum is the scientific approach aspect. The other three aspects that are the core and basic competences, the material appropriateness, and the assessment standards are good. However, they are required to improve in some aspects as follows: (1) 8 pairs of knowledge and skill basic competences that are not presented in this textbook (2) all the basic competences are not written in explicit and in detail in this textbook (3) the writing skills and group work are required to enrich (4) the attitude assessment standard is not presented in it. 
TABLE II. THE SUMMARY OF ANALYSIS OF THE CHARACTERISTICS OF 2013

CURRICULUM BASED ENGLISH TEXTBOOK FOR VII YEAR STUDENTS BY THE RESEARCHER AND THE EVALUATORS

\begin{tabular}{|c|c|c|c|}
\hline \multirow[t]{3}{*}{ No } & \multirow[t]{3}{*}{ Aspects } & $\begin{array}{l}\text { Mean Score/ } \\
\text { Percentage }\end{array}$ & \multirow[t]{3}{*}{ Explanations } \\
\hline & & Researcher & \\
\hline & & Evaluators & \\
\hline \multirow[t]{4}{*}{$\mathrm{a}$} & $\begin{array}{l}\text { The Core } \\
\text { competencies }\end{array}$ & \multirow[t]{4}{*}{3} & $\begin{array}{l}90 \text { - } 95 \% \text { of core competences and basic competences } \\
\text { are covered }\end{array}$ \\
\hline & \multirow{3}{*}{$\begin{array}{l}\text { Basic } \\
\text { Competencies }\end{array}$} & & good \\
\hline & & & $\begin{array}{l}\text { are } 8 \text { pairs of knowledge and skill basic competences that } \\
\text { are not presented in this textbook }\end{array}$ \\
\hline & & & $\begin{array}{l}\text { all the basic competences are not written in explicit and in } \\
\text { detail. }\end{array}$ \\
\hline $\mathrm{b}$ & $\begin{array}{l}\text { The Material } \\
\text { Appropriateness }\end{array}$ & 3 & $\begin{array}{l}90-95 \% \text { of materials covers the attitude, the knowledge, } \\
\text { and skill domains }\end{array}$ \\
\hline \multirow[t]{2}{*}{$\mathrm{c}$} & \multirow{2}{*}{$\begin{array}{l}\text { The scientific } \\
\text { Approach }\end{array}$} & \multirow[t]{2}{*}{4} & all the steps are covered \\
\hline & & & very good \\
\hline
\end{tabular}

\section{DISCUSSION OF THE FINDINGS}

The seven characteristics of a good English textbook and the four characteristic of the 2013 curriculum based textbook are required to improve in this textbook. The characteristics that should be improved are as follows:

\section{The Back Pages}

The back pages of 'BRIGHT 1' textbook are almost good. It only presents the bibliography and the back cover but the glossary and index does not exist in it. According to Brown (1995: 159-163), the organization of a textbook is one of the physical characteristic of a good textbook. A good textbook should organize the elements such as table of content, index, answer keys, glossary, and reference potential.

\section{The Balance of Chapter}

'BRIGHT 1' textbook does not have good unit/chapter balance. Some of chapters consist of $20-23$ pages. Whereas, some others are only 8-12 pages. Sheldon (1998: 242) mentioned that the length of unit is one of the factual details in a book assessment. 


\section{The Authenticity}

This textbook provides many of authentic materials such as photographs, recorded songs, lyric of songs, and street signs. Gebhard (1996) gives more examples of authentic materials that can be used by EFL/ESL teachers. He divided the authentic materials into two types that are authentic listening / viewing materials and authentic visual materials. The authentic listening / viewing materials include TV commercials, quiz shows, cartoons, new clips, comedy shows, movies, soap operas, professionally audio-taped short stories and novels, radio ads, songs, documentaries, and sales pitches. The authentic visual materials include slides, photographs, paintings, children's artwork, stick-figure drawings, wordless street signs, and silhouettes, pictures from magazines, ink blots, postcard pictures, wordless picture books, stamps, and X-rays. In addition, Nunan (1999) defines authentic materials as spoken or written language data that have been produced in the course of genuine communication, and not specifically written for purposes of language teaching. Jordan (1997) defines authentic texts as the ones that are designed for pedagogical aims. According to Carter \& Nunan (2001, p.68) authentic materials are "ordinary texts not produced specifically for language teaching purposes."

\section{The Topics}

This textbook covers very good topics. Most of the topics can be categorized as the interesting topics that are in reach to the students' knowledge and able to be practiced in their daily life. However, this textbook does not cover six topics in English subject for VII year students, as stated in 2013 curriculum. Cunningsworth (1995: 3-4) said that a good textbook should have sufficient materials of genuine interest to learners and enough variety and range of topic. Ur (2009: 186) mentioned that a good textbook should cover interesting topics and tasks. Brown (1995: 159163) also mentioned that the material should fit to curriculum means that requires some aspects such as approach, syllabus, needs, goal, objectives, and content. Moreover, Munkundan and Nimechisalem (2012) stated that a good textbook should match to the specification of syllabus and should be compatible to the interests of the learners. In other words, a good topic should be compatible to the learners' interest, should have variety and range of topic, and should fit to the syllabus of designed curriculum.

\section{The Macro and Micro Skill}

This textbook covers all the four macro skills and micro skills. All the skills are presented in grading activities/tasks. For the listening skill, this textbook accompanied by the recorder. Hutchinson and waters (1987: 94-97) said that one of content criteria of a good textbook is the proportion of work on each macro and micro skills. Harmer (1991: 281-284) explained about the skills aspect whether the materials include and practice the skills, have an appropriate balance of skills, the practice of individual skill integrated into the practice of other skills. Mukundan and Nimechisalem (2012) mentioned the criteria for the tasks in listening, speaking, reading, writing, vocabulary, grammar, and pronunciation. The listening tasks should meet the criteria such as well-defined goal, efficiently graded according to the 
complexity, and authentic or close to real language situation. The speaking tasks should meet the criteria such as meaningful communication and balance between individual response, pair work, and group work. The reading tasks should meet the characteristics such as graded and interesting. The writing tasks should meet the characteristics such as achievable goals and take into consideration learner capabilities. The vocabulary should meet the characteristics such as the appropriateness of load (number of new words in each lesson, a good distribution (simple to complex) of vocabulary load across chapters and the whole book, the efficiently repeated and recycled words across the book. The grammar should meet the characteristics that are contextualized and interesting. It is also introduced explicitly and reworked incidentally throughout the book. The pronunciation should meet the characteristics such as contextualized and learner-friendly with no complex chart.

\section{The Knowledge and Skill Basic Competences Completeness}

In accordance to the 2013 curriculum, there are 8 pairs of knowledge and skill in the basic competences that are not accommodated in this textbook. The unaccommodated basic competences are as follows: (1) 3.5 and 4.6 ask for names and numbers for animals (2) 3.5 and 4.6 ask for names and numbers for things (3) 3.7 and 4.8 the characteristics of people (4) 3.7 and 4.8 the characteristics of animals (5) 3.8 and 4.9 the behaviour of people (6) 3.8 and 4.9 the action of animals (7) 3.8 and 4.9 the functions of things (8) 3.11 and 4.14 songs. Brown (1995: 159-163) explained that a good material should match to approach (curriculum), syllabus, goal and objectives. Cunningsworth (1995: 3-4) mentioned that, in his quick reference checklist for evaluation and selection, a good textbook should have the closely correspondent of the aim of course book with the aims of the teaching program. Mukundan and Nimechcisalem (2012) also stated that a good textbook should match to the curriculum and the specification of syllabus.

\section{The Core Competence and the Basic Competence}

The Core Competence and the Basic Competence should be the references in determining the learning objective and the materials. In this textbook, both of the two competences are not written explicitly. The objectives, which are presented in the front page of each chapter, are presented in the forms of list of sentences without mentioning the number of Core and Basic Competences that will be reflected in each chapter. The materials in each activity/task also are not accompanied with the Core and Basic Competences that reflect them. Therefore, it can be stated the Core and Basic Competences are not written explicitly and clearly in this textbook. In relation to term of writing the explicit and clear Core and Basic Competences, Ur (2009:186) in his eighteen criteria four book assessment said that objectives explicitly laid out in an introduction and implemented in the material. 


\section{The Attitude Assessment Standard}

'BRIGHT 1 'textbook does not reflect the attitude domain in the assessment standard of 2013 curriculum as stated in the Ministry of Education and Culture Regulation No.66 Year 2013 and 81 A Year 2013. In this regulation, various kinds of techniques are provided for the attitude assessment standard. The assessment techniques include observation, self-assessment, peer-assessment, and journal. Hutchinson and Waters (1987: 94-97) mentioned in their checklist criteria of subjective and objective analysis about the attitudes to/expectation about the learning English. Brown (1995: 159-163) explained that a good materials should match to approach (curriculum), syllabus, goal and objectives. Mukundan and Nimechcisalem (2012) also stated that a good textbook should match to the curriculum and the specification of syllabus.

\section{Pictures}

The picture colour of this textbook is provided in very limited colours that are white, black and blue only. Ur (2009) said that the clear attractive layout is one of the criteria of a book assessment. In addition, Munkundan and Nimechcisalem (2012) mentioned in their textbook checklist evaluation sheet whether the layout is attractive. Brown (1995: 159-163) explained that some of the physical characteristics of a good textbook are highlighting, pictures, and text.

\section{CONCLUSION}

\section{'BRIGHT 1' textbook has reflected the characteristic of a good English textbook.}

This textbook has reflected seven characteristics of a good English textbook that are (1) the front pages that are cover page, copyright page, preface, and table of contents (2) the font is clear not too small or too big. (3) The chapter components that are objectives, explanations, activities, and evaluations (4) the grading tasks (5) the vocabulary explanation and tasks (6) the grammar explanation and tasks (7) the listening skill. The nine characteristics are not founded on the following aspects: (1) the back pages that are only the bibliography and the back cover (2) the pictures (3) the balance of chapter (4) the authenticity (5) the topics (6) the speaking skill (7) the writing skill (8) the reading skill (9) the pronunciation skill

'BRIGHT 1' textbook has reflected the 2013 curriculum: the Core Competences and the Basic Competences, the Scientific Approach, the Material Appropriateness and the Evaluation Standard.

The most prominent aspect that fulfils the appropriateness to the 2013 curriculum the strength is founded on the scientific approach aspect. It is presented very well in this textbook. The other three aspects that are the Core Competences and the Basic Competences, the material appropriateness, and the assessment standards are presented well in this textbook. However, they are need to be improved in some aspects as follows: (1) 8 pairs of knowledge and skill basic competences that are not 
presented in this textbook (2) all the basic competences are not written in explicit and in detail in this textbook (3) the writing skills and group work are needed to be enriched (4) the attitude assessment standard is not presented in it.

\section{IMPLICATION}

The findings of this research reveal that "Bright 1" textbook has some strength and some weaknesses that can be used as essential information for teachers in order to maintain the outcomes of learning for students. The textbook, as well as the teachers, has important rules as media that helps teachers in arranging materials and as an essential partner for the teachers in a teaching learning process. A textbook usually overcomes the whole school curricula, the aims, goals, even the materials. Therefore, by knowing the strength and the weaknesses of 'Bright 1 textbook', the teachers can add, delete, or modify some materials in the textbook. The teacher also can adapt the activities they should use in accordance with the condition of 'Bright 1' textbook.

For the material developers, the findings of this research can be used to improve their materials. They have important roles in providing an appropriate and ideal textbook for teachers and students. Thus, a qualified textbook can be used as a good media that contributes to the outcomes of learning for students.

The findings of this research also can influence to further research. It can be used for the other researcher as a reference or an insight in developing a similar research or other relevant research. Hopefully, the findings of further research will contribute the development of teaching learning materials.

\section{SUGGESTION}

\section{Suggestions for teachers}

This research has limited in providing some topics, some basic competences, the authenticity, the materials for teaching speaking, reading, writing, the phonetic transcription of pronunciation, and some materials for attitude assessment. Therefore, teachers can make additional materials for the lack of topics, for the authentic materials, for phonetic transcription, for reading, for speaking, and for writing.

\section{Suggestions for material developers and publisher}

The following are some suggestions for material developers and publishers. This textbook has strengths in the front pages, the font, the chapter components, the grading tasks, the grammar and listening activities, and the scientific approach steps. Material developers may include these concerns in their books.

On the other hand, there are weaknesses of this textbook in some aspects that are the back pages, the pictures' colour, the balance of chapter, the authenticity, the lack of some topics, the speaking material, the reading materials, the writing materials, the pronunciation transcription, the lack of some basic competences, and the materials for assessing attitude. Therefore, here are some suggestions for publishers, 
it is suggested that: First, the pages of each unit should be in range 18-22 pages. Second, the back-pages should be completed by the pages that cover glossary, index, and references/bibliography. The glossary and index do not exist in 'Bright 1' textbook. Third, the variation of colours should be enriched in this textbook so that it will motivate students to read and to learn it. Fourth, the lack of some topics and basic competences should be completed. All the topics and basic competences should be reflected the government regulation in the Appendix of Education and Culture Regulation No.68 Year 2013 that describes the content standard. Fifth, the materials for assessing attitude should be added in this textbook. The assessment techniques, as stated in the Ministry of Education and Culture Regulation No.66 Year 2013 and 81 A year 2013, include observation, self-assessment, peerassessment, and journal. Due to 'Bright 1' textbook is intended for students' book, the suitable techniques to be attached in this textbook are self-assessment and peerassessment. For the other techniques that are observation and journal, they are more suitable to be attached in teacher's book. Sixth, it suggested that this textbook is accompanied by the teacher's book that contains all the core and basic competences, syllabus, the procedure to use this book, and various kinds of assessment techniques.

\section{Suggestions for further research}

This research is limited only to the content analysis of 'Bright 1' English textbook for VII year students. Therefore, here are some suggestions for further research in details. First, the effectiveness of this research is not intended to the other grade such as grade VIII and IX. Moreover, the other researches, such as perspective and observation on these English textbooks are recommended to complete the previous one. Second, the document analysis as qualitative method is applied in this research, the result of this research is hardly able to be quantified and broadened and cannot be generalized in the evaluating and analysing the other textbook context.

\section{REFERENCES}

[1] Brown, H. (2007). Teaching by Principles an Interactive Approach to Language Pedagogy. New York: Pearson Education, Inc.

[2] Cunningsworth, A. (1995). Choosing Your Coursebook. Oxford: Macmillan Publishers Limited.

[3] Ellis, R. (1997). The empirical Evaluation of Language Teaching Materials. ELT Journal Volume $51 / 1,36-42$.

[4] Graves, K. (2000). Designing Language Courses: a Guide for Teachers. Boston: Heinle \& Heinle Publishers.

[5] Harmer, J. (1991). The Practice of English Language Teaching. Essex: Longman Group.

[6] Haycraft, J. (1978). An Introduction to Emglish Language Teaching. Harlow: Longman Group Ltd.

[7] Hutchinson, T., and Waters A. (1987). English for Specific Purposes A Learning Centeredapproach. Glasglow: Cambridge University Press.

[8] Kippendorff, K. (2004). Content Analysis an Introduction to Its Methodology. California: Sage Publication Inc.

[9] McDonough, J. e. (2013). Materials and Methods in ELT. Oxford: John Wiley \& Sons, Inc.

[10]Miles, M.B, and Huberman, A.M. (1994). Qualitative Data Analysis. California: Sage Publications Inc.

[11] Mohammadi, M \& Abdi, H. (2014). Textbook Evaluation: A Case Study. Procedia Social and Behavioral Sciences, 1148-1155. 
[12] Munkundan, J \& Nimechcisalem, V. (2012). Evaluative Criteria of an English Language Textbook Evaluation Checklist. Journal of Languange Teaching and Research, Vol.3, No.6, 1128-1134.

[13]Riasati, MJ \& Zare, P. (2010). Textbook Evaluation: EFL Teachers' Perspective on "New Interchange". Studies in Literature and Language Vol.1.No.8, 54-60.

[14]Richard, J.C. and Schmidt, R. (2010). The Dictionary of Language Teaching and Applied Linguistics. Harlow: Pearson Education Limited.

[15]Richards, J. (2013). Curriculum Approaches in Language Teaching: Forward, Central, and Backward Design. RELC, Journal 44 (1), 5-33.

[16] Sheldon, L. (1988). Evaluating ELT Textbook and Materials. ELT Journal, 42(4).

[17] Soleimani, H \& Dabbagi, A. (2012). Textbook Evaluation: A reflection on the New Interchange Series. International Journal of Research Studies in Language Learning, 19-32.

[18] Tok, H. (2010). Textbook Evaluation: From teachers' perspective. Educational Research and Review Vol.5 (9), 508-517.

[19] Tomlinson, B. (1998). Materials Development in Language Teaching. New York: Cambridge University Press.

[20]Tsiplakides, J. (2011). Selecting an English Coursebook: Theory and Practice. Theory and Practice in Language Studies, Vol. 1, No.7, 758-764.

[21]Ur, P. (2009). A course in Language Teaching Practice and Theory. Cambridge: Cambridge University Press.

[22] Wahab, A. (2013). Developing an English Language Textbook Evaluative Checklist. IQSR Journal of Research \& Method in Education (IQSR-JRME, 55-70. 